\title{
Variable retention harvesting in Great Lakes mixed-pine forests: emulating a natural model in managed ecosystems
}

\author{
Brian J. Palik ${ }^{*}$ (D) and Anthony W. D'Amato
}

\begin{abstract}
Variable retention harvesting (VRH) systems have gained wide use in many different forest types across the globe, but largely have been implemented in forests characterized by severe, infrequent disturbance regimes. There has been less attention given to developing VRH approaches in forests that are characterized as having a mixed-severity disturbance regime that often results in only partial mortality of canopy trees in spatially heterogeneous patterns. One example of such a forest type is red pine (Pinus resinosa Ait.)-dominated ecosystem of the western Great Lakes region of North America. The purpose of this review is to provide a conceptual foundation for developing VRH approaches in red pine ecosystems that are based on a mixed-severity disturbance regime. Our contention is that red pine forests managed following a natural model are more resilient to disturbances and external threats such as climate change.

For the red pine ecosystem, VRH application should reflect the often severe, but partial canopy removal from natural disturbance that is characteristic of this ecosystem and that results in more than trivial numbers of surviving overstory trees across a range of spatial configurations in regenerating stands. Retained live trees should span a range of diameters, but favor the larger end of the diameter distribution, as this reflects the likely pattern of survival after natural disturbance and is often a key structural element lacking from managed areas. VRH should be applied in ways that vary the spatial pattern of legacy trees in and among stands, but largely in ways that reflect the pattern of spatially patchy canopy structure, with large openings surrounded by a less disturbed matrix, as occurs with a natural disturbance regime. Legacy trees and deadwood structures should reflect the composition of the pre-disturbance forest, including species in addition to dominant red pine. Finally, retained structures should be viewed as dynamic entities that grow, die, and decay and that need to be documented and accounted for over time.

While more organizations are incorporating some form of VRH into policy and practice for red pine-dominated ecosystems, this application is not always based on a comprehensive understanding of the actual natural model of development, which reflects a mixed-severity disturbance regime. Our goal is to review the ecological evidence for this disturbance regime and interpret the structural and compositional outcomes of the disturbance model, so as to advance VRH approaches that better emulate the actual disturbance and development model for this regionally important ecosystem.
\end{abstract}

Keywords: Red pine, Mixed-severity, Variable retention, Natural disturbance

\footnotetext{
*Correspondence: brian.palik@usda.gov

'USDA Forest Service, Northern Research Station, Grand Rapids, MN 55744,

USA

Full list of author information is available at the end of the article
} 


\section{Introduction}

Variable retention harvesting (VRH) systems have gained wide use in many different forest types across the globe (Gustafsson et al. 2012). The rationale for VRH is that even the most severe natural disturbances are often not stand replacing and in fact varying amounts of overstory trees escape mortality and significant amounts of large deadwood is created by and remains after the disturbance (Franklin et al. 2000, 2018). VRH applied in this context can better emulate the structural and compositional outcomes of natural disturbance by leaving varying amounts of large live trees, by retaining existing large deadwood including logs and snags, or by creating deadwood from live trees at the time of harvest. Increasingly, VRH used in this way is one component of a more comprehensive ecological approach to silviculture (D’Amato et al. 2016; Palik and D'Amato 2017).

The ecological principle addressed by VRH is that of continuity of structure, composition, and function between the pre- and post-disturbance forest (Palik and D’Amato 2017; Franklin et al. 2018). Use of VRH to emulate natural disturbance in forests managed for timber better ensures some degree of continuity in microclimates, habitat features, and resource environments, compared to forests managed without significant legacy retention. As a consequence, such forests are positioned to sustain the full complement of native species and ecosystem processes that are found in the early post-disturbance environment after natural disturbance and may be more resilient to external threats such as climate change, invasive species, and novel disturbances.

VRH as described is readily applied in forests that experience severe, infrequent canopy disturbances that leave legacy structures behind, such as Douglas-fir (Pseudotsuga menziesii (Mirb.) Franco)-dominated forests in the Pacific Northwest or mountain ash (Eucalyptus regnans F. Muell.) forests of southeastern Australia (Franklin et al. 2018). Often, these and similar types of forests have been managed historically using even-aged regeneration systems, typically with little retention. A justification for use of the latter management approach has been that it in fact emulates the natural model of stand-replacement disturbance, but ample research in forests characterized by severe, infrequent disturbances demonstrates that VRH approaches better emulate the natural model (e.g., Hansen et al. 1991; Bergeron et al. 1999; Kuuluvainen and Siitonen 2013).

There has been less attention given to developing a rationale and approach for VRH in forests that are better characterized as having a mixed-severity disturbance regime, where disturbances can be more frequent, may range in severity within and among stands, but often result in only partial mortality of canopy trees in spatially heterogeneous patterns. An example of an ecosystem that fits the mixed-severity disturbance archetype is the mixed-pine forests and woodlands that occur on xeric to dry-mesic sites in the western Great Lakes region of North America. These ecosystems are dominated by red pine (Pinus resinosa Ait.), often with shared importance of eastern white pine (Pinus strobus L.), and with varying amounts of other conifers and hardwood species. Mature and old-growth stands often have complex age structures, abundant large deadwood, and heterogeneous canopy conditions. The characteristic disturbance agent in these ecosystems is fire. Importantly, fires that kill overstory trees are patchy within stands, and thus, they can be less than stand replacing and certainly vary in their severity across a landscape.

Historically, red pine forests have been managed in ways similar to the severe, infrequent disturbance forest type by using even-aged regeneration systems with little to no meaningful retention. More recently, when VRH is applied in these forests, it mirrors its application in forest characterized by severe, infrequent disturbances, by using largely even-aged regeneration systems with the addition of some low level of retention (e. g., Minnesota Forest Resources Council 2013). The distinct difference in the disturbance regime and resultant structural and compositional features of red pine forests, compared to forests characterized by a severe, infrequent disturbance regime, suggests a need for a different approach to VRH in the former, if emulation of a natural model is the goal.

The purpose of this paper is to provide a conceptual foundation for use of VRH in red pine-dominated ecosystems in ways that emulate the natural model of disturbance and development. Specific objectives include: (i) reviewing the evidence for a mixed-severity disturbance regime in red pine-dominated ecosystems, (ii) developing a framework for VRH approaches that emulate the natural model, and (iii) examining real world examples of VRH in red pine ecosystems that are based on the natural model.

\section{Red pine ecosystems of the Western Great Lakes region, North America}

Historically, red pine-dominated ecosystems were an important component of the landscape on dryer sites in the western Great Lakes region of North America, including northern Wisconsin, Michigan, and Minnesota in the United States (US) and southern parts of Ontario and Manitoba in Canada. These forests occupied over 4 million ha in the US alone prior to significant Euro-American settlement (Frelich 1995). Red pine, along with eastern white pine, is the dominant tree species on these sites, with varying amounts of other species, including balsam fir (Abies balsamea (L.) Mill), white spruce (Picea glauca (Moench) Voss), jack pine 
(Pinus banksiana Lamb.), trembling and bigtooth aspen (Populus tremuloides Michx., Populus grandidentata Michx.), red maple (Acer rubrum L.), northern red oak (Quercus rubra L.), bur oak (Quercus macrocarpa Michx.), and paper birch (Betula papyrifera Marshall).

Although greatly reduced in area in the contemporary landscape, red pine-dominated forests are still an important timber resource in the region. For example, the province of Ontario, Canada, reported having over 1 million ha of red pine forest (reported with eastern white pine) in 2011 (Watkins 2011) and over $156,000 \mathrm{~m}^{3}$ of red pine was harvested in 2012-2013 from these forests (https://www.ontario.ca/page/annual-report-forest-management-2012-2013). In the three US Lakes States of Minnesota, Wisconsin, and Michigan, the estimated area for red pine forests in 2016 was over 800,000 ha (USDA Forest Service Forest Inventory Data Online; http://fs. fed.us/fia/fido/index.html). Harvested volume in 2016 of red pine was over 1.6 million $\mathrm{m}^{3}$. Most of this resource is managed using a timber-focused model, generally consisting of even-aged regeneration systems, planting of red pine, little attention to maintaining or restoring diversity of co-occurring tree species, and little to no meaningful retention. Although this model represents an efficient strategy for maximizing stand-level, crop-tree production, it results in substantially different structure and composition than does the natural model.

\section{Natural disturbance regime}

The natural disturbance/development model for the red pine ecosystem is one in which fire plays a prominent role, both as surface and crown fire. In the classical interpretation of the disturbance regime, frequent, low severity surface fire, with return intervals on the order of 5 to 50 years, reduces hardwood competitors, thins populations of pines, and maintains an open woodland structure, with patchy open $(50-75 \%)$ canopy cover (MN DNR 2003). Infrequent stand-replacing crown fire is thought to occur with a return interval of $150-250$ years (Heinselman 1996), resulting in the regeneration of even-aged stands; however, this assumed age structure and disturbance regime is largely derived from reconstructed ages obtained from a handful of trees in old-growth stands, as opposed to detailed population-level surveys.

A large body of research over the past century demonstrates that the actual disturbance/development model for red pine ecosystems is more complex than the widely-popularized, classical interpretation described above. This work demonstrates that, historically, fires were quite frequent, with mean return intervals ranging from 9 years and up to 23 years (Guyette et al. 2015; Drobyshev et al. 2008a). There is a suggestion that this variation was related to Native American burning activity, with shorter return intervals associated with more active use areas. On top of anthropogenic ignition, lightning likely is also an occasional source of ignition (Loope and Anderton 1998). Frequent surface fires served to reduce the abundance of rhizomatous shrub species (e.g., Corylus spp.) and reduce litter layer thickness, allowing for successful pine recruitment following canopy disturbance.

Lower intensity surface fires periodically intensified, resulting in significant mortality of canopy trees, but often in localized within-stand patches as opposed to complete stand-replacement (Bergeron and Brisson 1990; Drobyshev et al. 2008a, b; Fraver and Palik 2012). Early researchers often noted the complex age and canopy structures of old red pine stands (Bergman 1924, Shirley 1932, Eyre and Zehngraff 1948), recognizing that these conditions likely developed from less than stand-replacement fire and, quoting Shirley (1932), were "typical of the forest."

While complex age and canopy structures largely result from the heterogeneous nature of the fire regime, there is some evidence for gap or patch-scale tree mortality from wind and fungi in the Armillaria genus (see McLaughlin 2001; Fraver and Palik 2012; Silver et al. 2013). These latter disturbances may be important drivers of heterogeneous stand structures, essentially reinforcing the heterogeneous structure resulting from patchy fire, and also may be important for promoting alternation between hardwood and conifer dominance at small patch-scales.

Early twentieth century photographs illustrate the structural characteristics that result from this disturbance regime, including patchy canopy structure, multiple age-cohorts, and regeneration in gaps (Fig. 1). Quantitative evidence for the disturbance regime and resultant structure comes by way of stand reconstructions in Minnesota, USA (Fig. 2; Fraver and Palik 2012). These demonstrate that in the past, disturbance dynamics were somewhat variable across the regional landscape, as reflected in the variable red pine age structures, but at the stand-scale, partial canopy disturbances were common leading to new cohorts establishing in close proximity to older cohorts. This interpretation is supported by research from other areas in the Lake States and Canada (Bergeron and Brisson 1990; Drobyshev et al. 2008a, b).

\section{Legacy characteristics}

Structural legacies, including live trees and deadwood, are an important attribute of early successional red pine ecosystems after the disturbances summarized above. A key distinction from legacy characteristics associated with the severe, infrequent disturbance type, such as occurs with Douglas-fir-western hemlock (Franklin et al. 

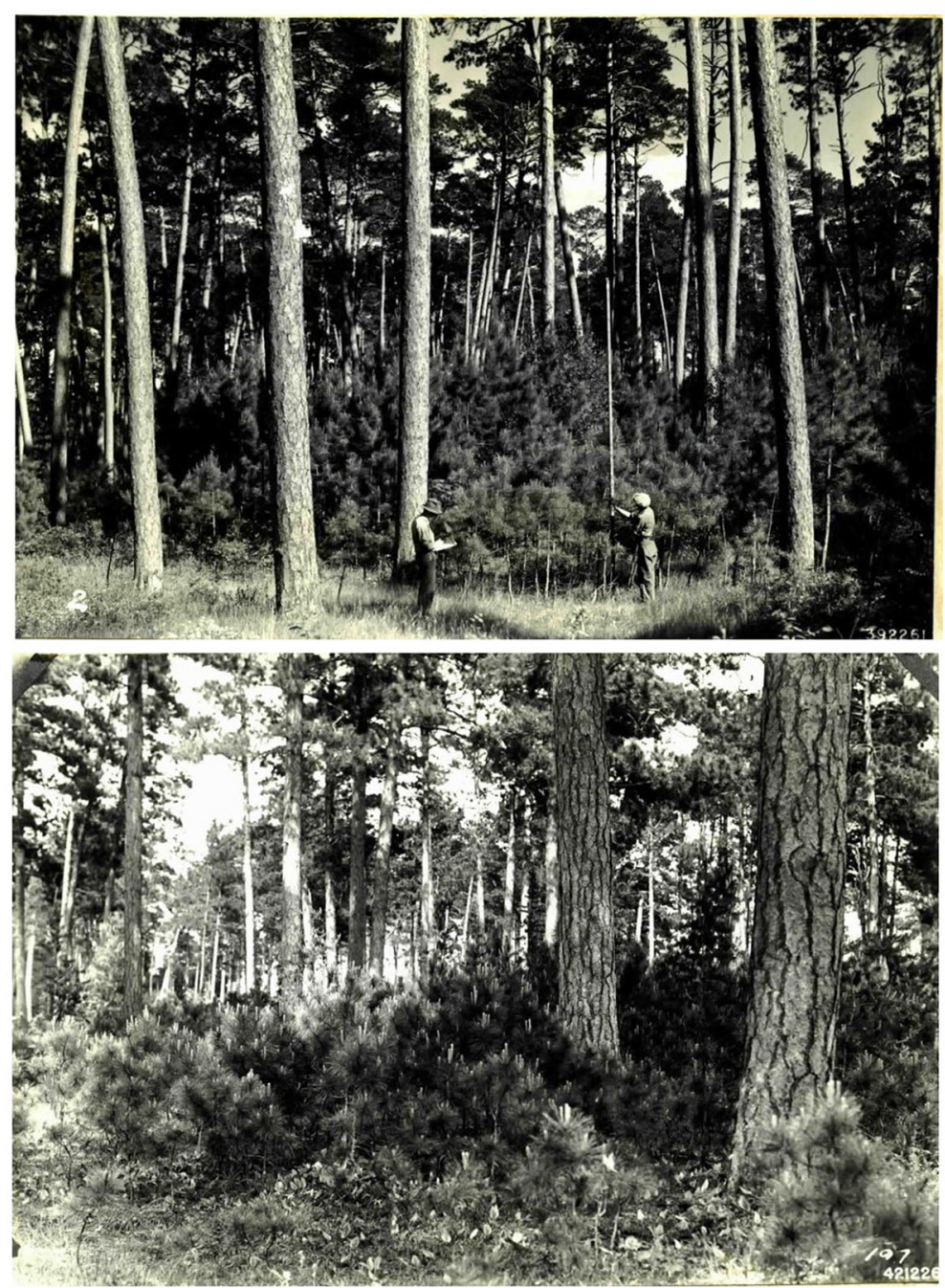

Fig. 1 Historical photo documentation of large gap regeneration and heterogeneous canopy structure in red pine-dominated ecosystems (colloquially referred to as Norway pine). The photos, taken in 1939, are from what is now the Chippewa National Forest, MN, USA. Top: The caption for this photo reads nature's own group selection: red pine reproduction often became established in great abundance following a seed year, but because of the density of the overstory such reproduction was generally shaded out within a few years except in openings caused by tree mortality. Bottom: Large old pines and red pine cohort regeneration, Pike Bay, MN, USA

2018), is that red pine ecosystems are characterized by lesser amounts of deadwood, greater numbers of live tree legacies, and greater spatial heterogeneity of arrangements at within-stand spatial scales, reflecting the often less than stand replacing and patchy nature of disturbance (Fig. 3).

The spatial heterogeneity of disturbance and legacy creation can be surmised by examining a characteristic tree establishment map from an old-growth stand (Fig. 4). This example suggests that after disturbances that initiate new cohorts, the distribution of residual trees is spatially heterogeneous, due to varying spatial severity of disturbance. In addition, the intermingling of cohorts in portions of the stand highlights the importance of gap-scale events in generating fine-scale, within-patch heterogeneity in structure and composition.

Most legacy trees left after canopy disturbance are red pine, with some eastern white pine, reflecting the dominance of these species in the old and mature forest stages. Trees likely are complex structurally, with large branch systems, thick bark, buttressed roots, and cavities, and span the range of sizes found in the mature and old forest. Legacy trees from other species, largely fire-sensitive species, are occasional and likely found in patches of unburned forest. These areas also have a well-developed shrub layer, whereas areas experiencing more frequent surface fires have lower shrub abundance and seedbed conditions more receptive for red pine establishment. Snags and dead trees from the 

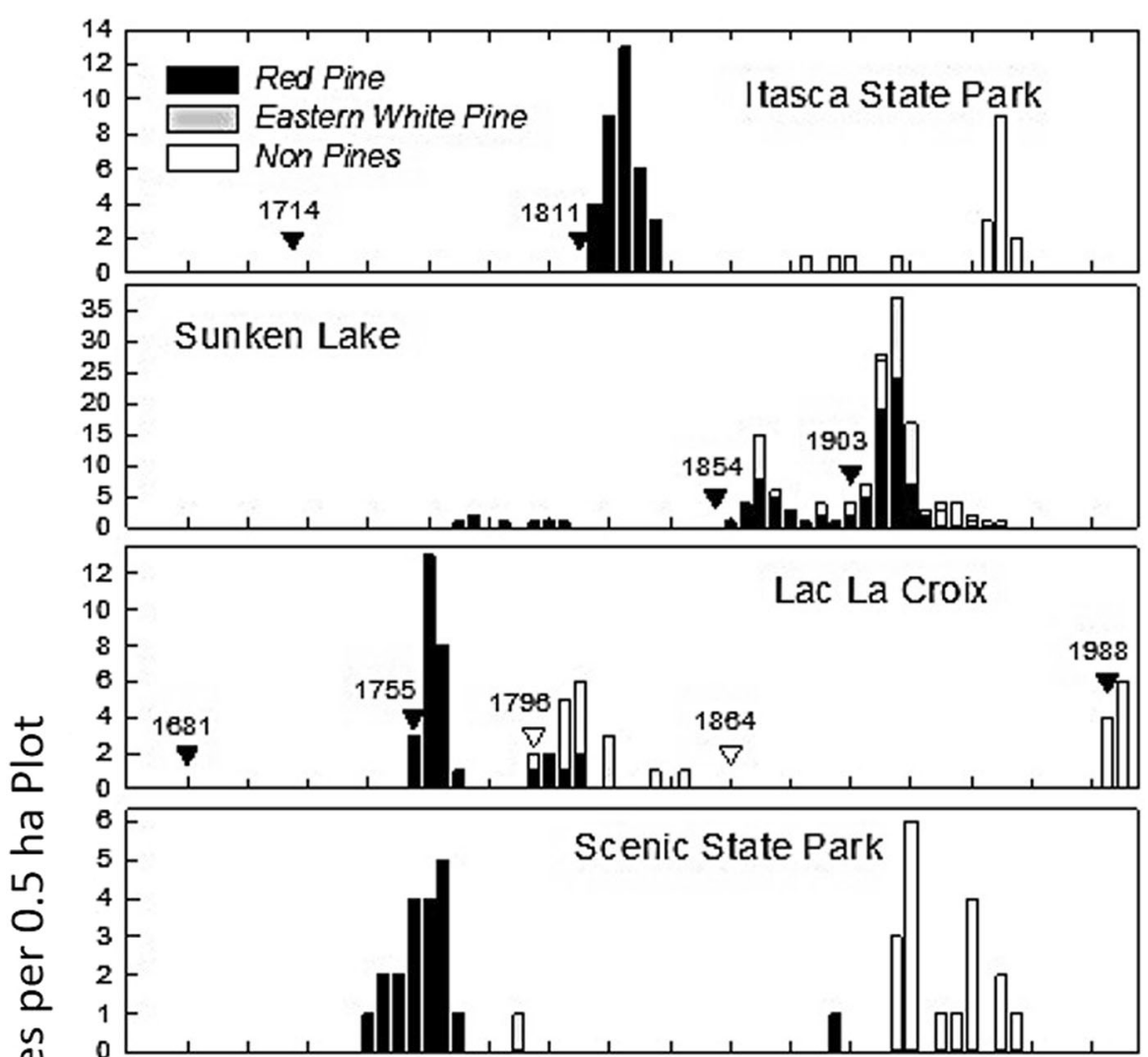

$\stackrel{1}{\stackrel{2}{上}}$
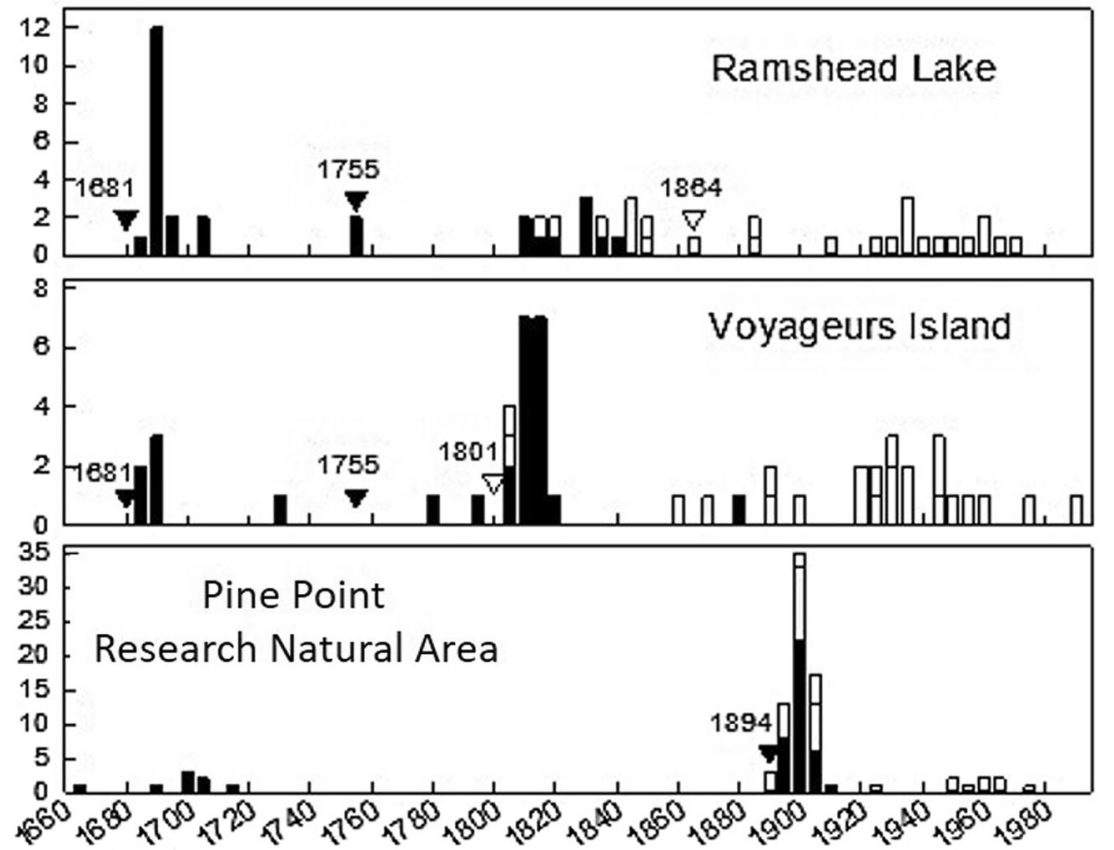

Establishment Date

(5 year intervals)

Fig. 2 Age structures for old-growth red pine-dominated stands in MN, USA, showing a variety of forms, including broadly single-cohort, twocohort, and three-cohort structures. Dates are known fire occurrences. Solid triangles denote known fire dates in each stand; open triangles denote known fire dates from nearby stands. Redrawn from Fraver and Palik 2012 


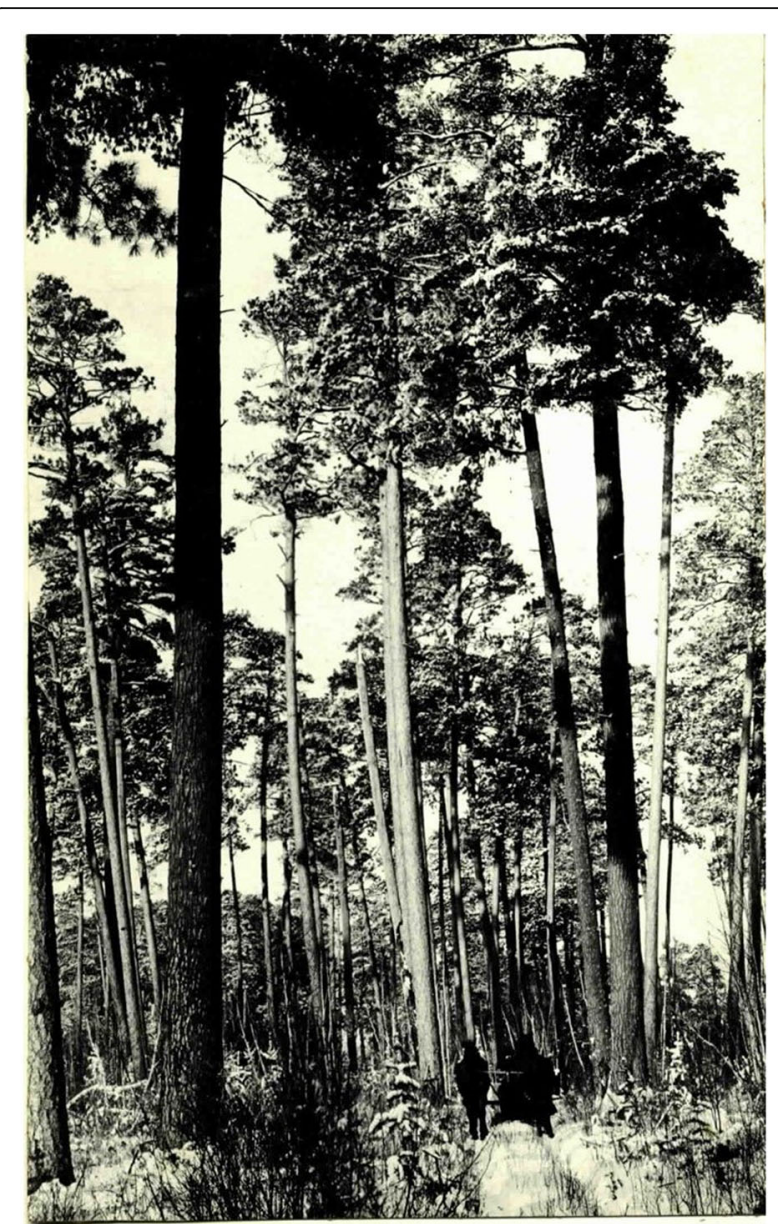

Fig. 3 Old red pine stand after a partial canopy disturbance, leaving residual live tree legacies. Circa early twentieth century, Chippewa National Forest, MN, USA

pre-disturbance stand include large red and eastern white pines, but also larger individuals of other species in proportions that reflect their live tree abundance in the pre-disturbance forest. After a more severe fire, newly generated deadwood legacies will be well represented by fire-sensitive species.

The key messages here, that have application to designing VRH systems, are that (i) regeneration disturbances often result in patchy, partial overstory mortality with new cohort establishment in patches and in close proximity to surviving overstory trees, (ii) there is spatial heterogeneity in the distribution of legacy structures and canopy characteristics within and among stands, and (iii) legacy trees and structures reflect the species composition and size and age distribution of the pre-disturbance forest. We will next explore how this insight into natural disturbance and legacy characteristics can be used to develop VRH approaches that better emulate the natural model of disturbance for this ecosystem.

\section{Translating a natural model into VRH approaches}

A useful framework for developing a VRH approach that is based on a natural model of disturbance is to answer four fundamental questions (Franklin et al. 2007), specifically: what to retain, how much to retain, what is the appropriate spatial pattern of retention, and how to account for retention over time. For the red pine-dominated ecosystem, the variation in the natural model of disturbance among stands in a landscape (e.g., Fig. 2) suggests that a spectrum of answers to these questions may be possible, but the answers still need to fall within boundaries defined by the natural model. We will address each of the questions below in the context of our understanding of the natural disturbance regime and its structural and compositional outcomes for the red pine ecosystem.

\section{What to retain? \\ Structural retention}

The obvious answer to the question of what to retain is live trees. The less obvious answer is that attention should be given to retaining trees from across a range of diameters, inclusive of the largest individuals in the stand, since partial disturbances by definition leave large trees alive. In the case of surfaces fires that are severe enough to cause mortality of overstory trees, the largest individuals are likely to be the most resistant to mortality from fire, so emulation of this disturbance outcome with VRH should include large individuals. Surface fires that develop into crown fires in patches will also leave large individuals alive, either in the matrix between mortality patches or occasionally within the patches themselves. Specific size recommendations for retention are not possible, since diameter distributions and maximum sizes will vary with stand age, past treatments and disturbance, and site conditions. However, a general rule of thumb is that $75 \%$ of retention tree should come from the top $25 \%$ of the diameter distribution.

The condition of retention trees should be considered. Retained trees should span a range of qualities if possible, inclusive of large, vigorous trees, as well as decadent, decaying, and declining trees, as would be the case after natural disturbance. Regeneration harvests conducted as part of timber-focused management rarely leave high quality trees behind in any significant number. Historically, when retention has been included as part of timber-focused management it often is focused on trees with limited growth potential, i.e., cull trees (Fig. 5). Also with timber-focused approach, trees in an obvious state of decline due to diseases, pests, or other causes would rarely be retained; in fact these individuals often are the target of removal during earlier thinning harvests, providing little opportunity for retention during regeneration harvest. Some of these declining trees 


\section{- Red Pine 1770 \\ - Red Pine 1854 \\ Sunken \\ - Red Pine 1903 \\ - White pine (all) \\ Lake}

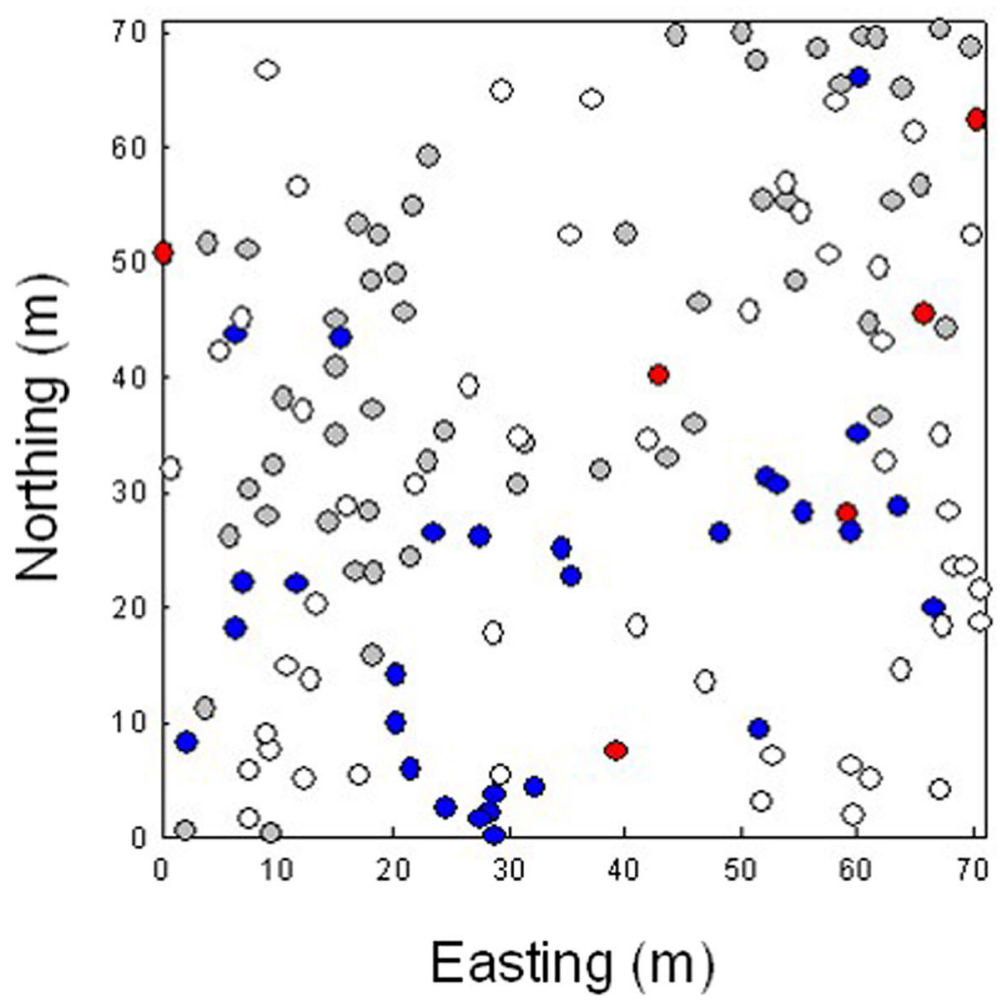

Fig. 4 Stem map of trees in the Sunken Lake old-growth red pine-dominated stand in MN, USA. Red pine trees are listed according to cohort establishment dates; establishment dates for eastern white pines are pooled. Redrawn from Fraver and Palik 2012

will survive natural disturbance, especially in patches of forest skipped by disturbance, or in fact be created by the disturbance itself. If they are present at the time of VRH, particularly as larger individuals, some should be retained for habitat value, for future cavity development, and as a likely near-future source of snags and downed large wood.

Mature red pine-dominated stands will likely contain some large snags and logs on the ground (e.g., Fraver and Palik 2012); if these exist in a managed setting, as many as possible should be retained at harvest, given deadwood abundance is often low in managed red pine stands (Silver et al. 2013). Moreover, snags and logs should be retained across the range of decay classes present. As with live trees, specific size recommendations for retention of deadwood is difficult, as snag and log diameters will vary with site and stand conditions. A general rule of thumb is that all snags above $30 \mathrm{~cm}$ in diameter should be retained, as this is the minimum diameter to have functionality for cavity nesting birds. Also, deadwood on the ground that is $30 \mathrm{~cm}$ or greater in diameter at the large end should be protected from damage.

\section{Compositional retention}

While there are several elements of composition that might be considered with VRH, including retention of non-tree vegetation or protection of advance tree regeneration, here we focus on the species composition of legacy trees. Most retained trees will be red pine and eastern white pine, as these generally are the most abundant species in the ecosystem. However, attention should also be given to retaining some of the richness of other tree species that can occur in this ecosystem. Many of these other species are fire-sensitive, so with a natural fire regime, most would survive as legacies in patches of forest that were skipped by fire. In a managed stand, identifying individuals and populations of these species prior to harvesting and then associating them with retention aggregates, which are patches of retained trees (see below: Spatial pattern of legacies in a stand?), so 

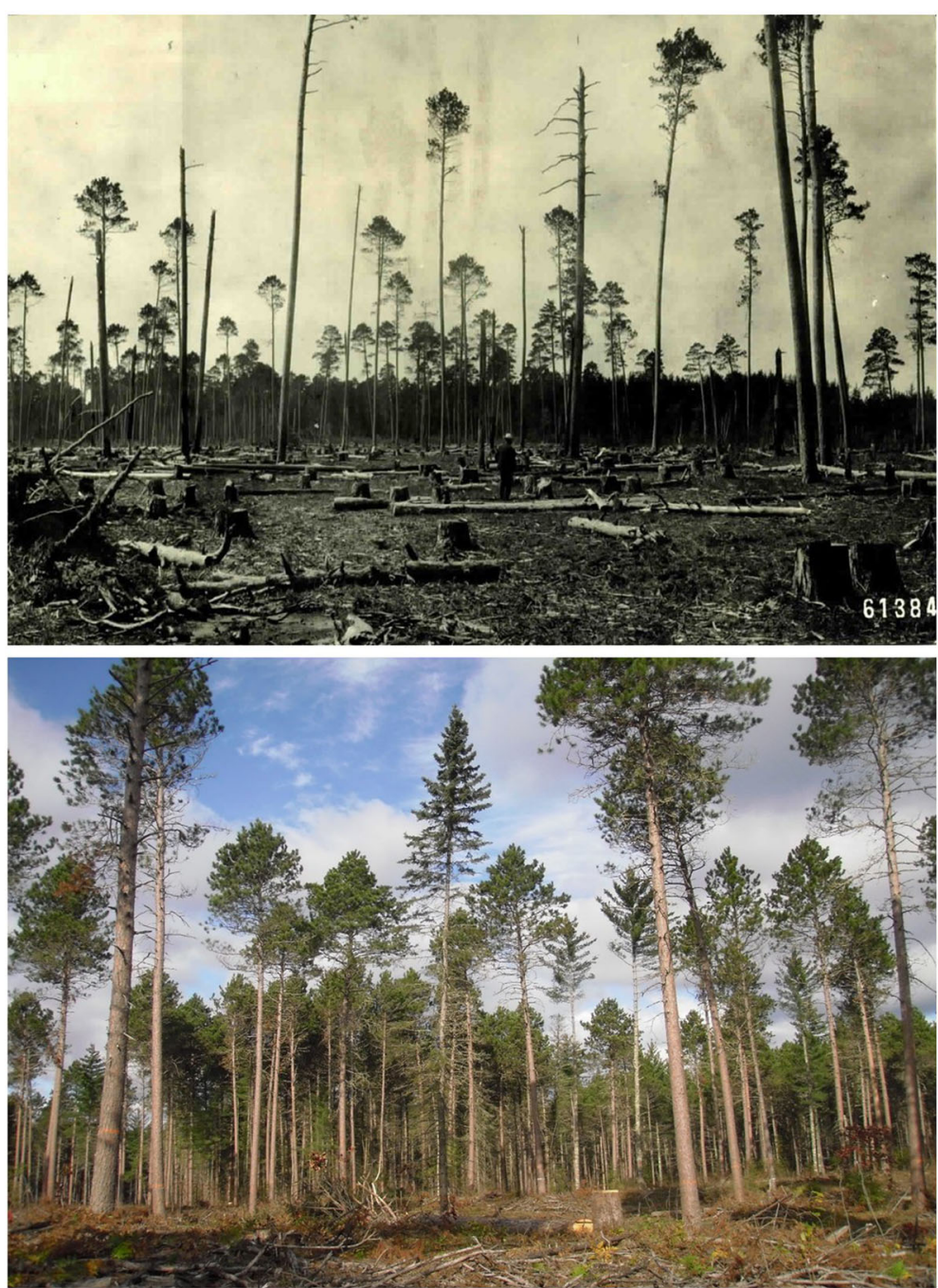

Fig. 5 Top: Poor quality and low level of retention after an early regeneration harvest on the Chippewa National Forest, MN, USA (circa early 1900s). Bottom: Higher quality and higher density of retention trees after a VRH on the same national forest (circa 2014)

that they include these populations is an appropriate way to emulate the natural model of disturbance.

\section{How much to retain?}

The second question to answer when designing a VRH approach that emulates the natural model is how many legacies to retain. For red pine ecosystems, the answer for legacy trees is that some is better than none because, as reviewed previously, legacy retention has not been practiced in any appreciable way in stands managed for timber. Unfortunately, answering the question in this way can lead down a path of treating stands with even-aged regeneration systems that include some typically low amount of retention, that is, so called clear-cut with reserves. As discussed previously, this is in fact an emulation of the severe, infrequent disturbance regime, rather than the more appropriate mixed-severity disturbance regime. When emulating the latter disturbance regime with VRH, the answer to the question of how much to retain is more appropriately "more is better than some," reflecting the potential for patchy, often less than stand-replacing natural disturbance that can leave significant amounts of live trees standing.

The density of trees to retain during VRH, to emulate the natural model, is difficult to determine from stand reconstructions alone, but still these data sources still can be used as a general guide (e.g., Fig. 2). Such reconstructions are a snapshot of the structure of the stand at the time of sampling. Presumably, some number of the trees from older cohorts have died since these trees reached the main canopy of a stand. Thus, using their number to guide VRH is suggestive but not definitive of retention tree density. 
The best example of using age reconstructions to guide VRH is the Sunken Lake stand in Figs. 2 and 4. This stand contains three pine cohorts, two of which are young enough to be suggestive of tree density in the older cohort at the time of establishment of the younger cohort. In the Sunken Lake stand, red pine and eastern white pine in the 1903 cohort established in openings within the 1854 cohort. Likely, there were more 1854 cohort canopy trees alive in 1903 than there were at the time of age sampling. However, the number of 1854 trees that have died between the times of their canopy ascension and sampling may actually be small, as red pine and eastern white pine are a long-lived species (300 + years) and, as mentioned above, large, old individuals are particularly resistant to surface fires. Based on this example, it is reasonable to say that a minimum number of large retention trees in a VRH harvest that is patchy and less than stand replacing might be at least 76 per ha, which is the number of 1854 cohort trees alive at the time of sampling. If we assume an average diameter of $40 \mathrm{~cm}$ for these trees, then this number corresponds to a retained basal area of approximately $9.6 \mathrm{~m}^{2} /$ ha. Historical photographs of old-growth stands after natural disturbance are supportive of this general density and stocking as well (Figs. 1 and 3).

Other stands in Fig. 2 have cohorts that are too old to make this same kind of interpretation, because too many trees have likely died since they ascended to the main canopy or they are broadly single-cohort (e.g., Itasca, Scenic). However, even for the latter, it should be noted that the single cohorts reflect establishment over 50 to 70 years, calling into question any attempt to label these as even-aged stands, and refuting use of an even-aged regeneration system with narrow age variation to emulate a natural model. Even in these stands, there were new individuals establishing in proximity to the oldest individuals in the cohort. Moreover, in both cases, the single cohorts were old enough that there were likely individuals of an even older cohort alive at the time of initiation of the younger cohort, but that were dead by the time of sampling, as was the case in all the other examples.

The complements of the live trees are deadwood structures generated by natural disturbance. Even with partial stand-replacement disturbance, there will be a lot of deadwood created within the disturbed area. In managed stands, large deadwood structures are often lacking; thus, the VRH may be an opportune time to emulate deadwood dynamics by creating some snags and logs using the equipment on hand. Obviously, a forester would not consider close emulation, as the numbers of snags or logs after natural disturbance may be high. For example, snag densities can range from 24 to 166 stems per hectare in old-growth red pine forests (Silver et al.
2013); such levels of snag and deadwood would be economically and operationally unfeasible. Rather, an acceptable rule of thumb is to create three to five logs and snags per hectare that are $30 \mathrm{~cm}$ or greater in diameter, with the assumption that mortality of retained live trees will provide more of these legacies over time.

\section{Spatial pattern of legacies in a stand?}

The third question to answer is where and how to retain legacies in a stand, that is, what is the spatial pattern of retention in the harvest unit. In general, the answer is typically put into the context of dispersed versus aggregated retention. Consideration of spatial pattern of retention is important because some objectives are best met with dispersed retention and others with aggregated retention (Franklin et al. 2007; Aubry et al. 2004; Franklin et al. 2018). The dispersed versus aggregated contrast is readily visualized in forests characterized by severe, infrequent disturbances. VRH approaches in these forests will include low to moderate levels of retention in either dispersed or aggregated patterns, or some combination of the two, to emulate the natural model of disturbance and development.

Spatial pattern of retention is also a consideration in red pine forests characterized by mixed-severity disturbance regimes. Here, the options for variation in pattern are likely to be even greater than in the severe, infrequent disturbance archetype (Fig. 6). Patterns of retention that reflect the range of variation in the natural model of disturbance may range from moderate levels of dispersed retention (Fig. 6a) to various forms of aggregated retention. The latter may take the form of retention aggregated into patches in the harvest unit, with or without some dispersed trees between aggregates in the cut matrix (Fig. 6b, c), and may be most suitable if regeneration goals emphasize recruitment of species of lower shade tolerance. The pattern may include large openings as the dominant feature of the harvest, with retention occurring in, around, and between openings (Fig. 6d-f). The possible patterns are numerous and all emulate to varying degrees the potential patterns of surviving trees after natural disturbance.

\section{How to account for retention over time?}

The final question to answer is a temporal one, specifically, how can a forester integrate the natural dynamics of retained legacies into future silvicultural activities. Retained trees and deadwood structures are not static elements of a stand. Rather, retention trees continue to grow in size and as they age they will develop unique structural attributes, such as deeply furrowed bark, large lateral branches, or cavities. Also, retention trees may die and transition to the deadwood pool and within this 

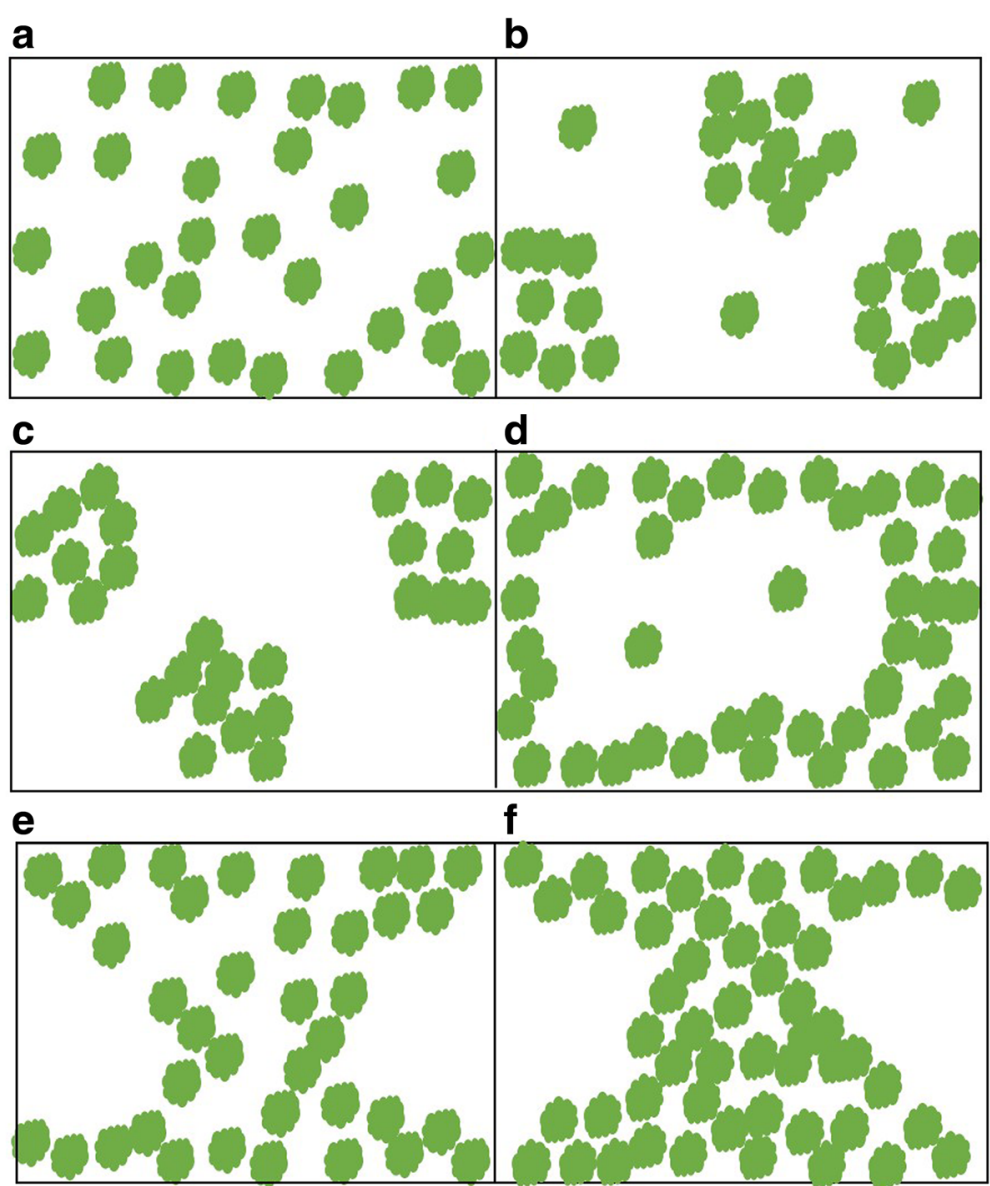

Fig. 6 Conceptual representation of various types of variable retention harvesting in red pine ecosystems. Retention may be implemented as dispersed trees (a) or aggregated with or without some dispersed trees in the harvested matrix $(\mathbf{b}, \mathbf{c})$. Alternatively, retention may be implemented as large gap (patch) openings with a few retained trees in the opening (d) or as smaller patch openings with or without thinning of the forest between the openings $(\mathbf{e}, \mathbf{f})$

pool, snags may transition to downed logs and these logs will progress through various stages of decomposition.

Future silvicultural treatments conducted after the initial VRH need to account for these dynamics in order to sustain the functionality of legacies and to emulate the natural model of development for the ecosystem. A key component of this emulation should include allowing some portion of tree legacies to live out their natural life cycle, including growth, structural development, and mortality, rather than treating these retained trees as crops to be removed in a second harvest entry, as might be done in a shelterwood regeneration system.

The transition into and through the deadwood pool (mortality, fragmentation, decomposition) warrants special temporal consideration as well. While retained pines may survive for decades or even well over a century depending on their age at the time of VRH, these trees will eventually die and transition into the deadwood pool (Fig. 7). Moreover, large snags will decay and fall and large logs on the ground will decompose. Silvicultural

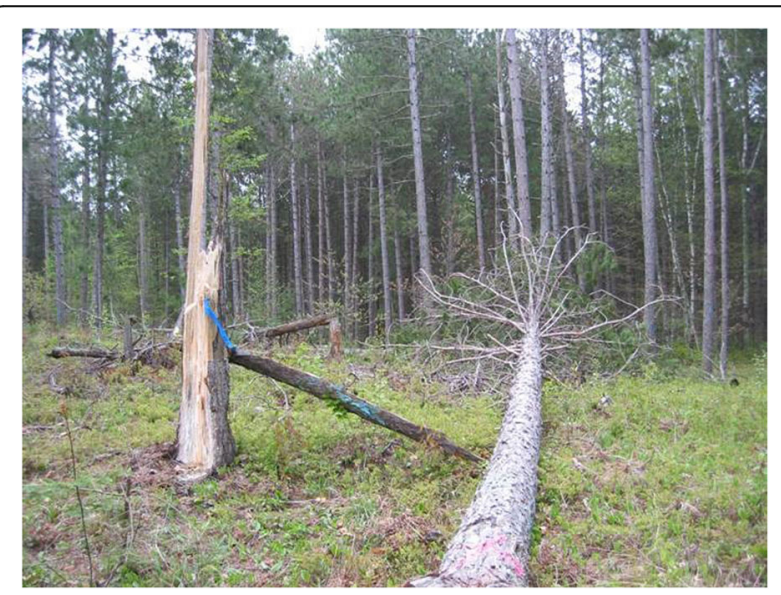

Fig. 7 This retained live red pine was snapped in a windstorm, increasing its ecological footprint in the stand; the resultant footprint should be buffered in future entries, so as to sustain the functioning of both the snag and downed log 
prescriptions should anticipate these dynamics by, for instance, allowing for an expanding no-traffic buffer around these structures so as to sustain their functionality over time.

Sustaining the functionality of retained structures overtime requires careful documentation of legacy location, particularly of the largest trees, snags, and downed logs in the stand. This should be accompanied by clear descriptions of the long-term objectives for retention to ensure future harvests do not remove retained trees or heavily impact areas near aggregates or retained deadwood structures.

\section{Summary}

Answering the four fundamental questions about VRH in the context of a natural model of disturbance and development for red pine ecosystems leads to some generalities that apply to many settings. First, VRH applications should reflect the often extensive, but partial canopy removal by natural disturbance that is characteristic of this ecosystem and results in anywhere from 10 to $60 \%$ of legacy trees surviving in regenerating stands. It is important to recognize that greater numbers of legacy trees will survive than if this ecosystem was consistently associated with a severe, infrequent disturbance regime.

Second, retained live trees should span a range of diameters, but favor the larger end of the diameter distribution, as this reflects the likely pattern of survival after natural disturbance and focuses retention efforts on structural elements largely lacking from managed landscapes.

Third, VRH should be applied in ways that vary the spatial pattern of legacy trees in and among stands, but largely in ways that reflect the pattern of spatially patchy canopy structure, with large openings surrounded by less disturbed matrix, as occurs with a natural disturbance regime.

Fourth, with VRH, legacy trees and deadwood structures should reflect the composition of the pre-disturbance forest. For the red pine ecosystem, most trees, snags, and logs will likely be red pine, but eastern white pine and other tree species should be included if they occur in the stand.

Finally, the long potential life spans of red and eastern white pines, with associated growth and structural development even after a disturbance, and the long potential tenure of legacy snags and down logs, require VRH approaches that incorporate plans for documentation of retained structures and clearly stated long-term objectives for their management to maintain functionality.

\section{Variable retention harvesting in practice}

Over the last decade, many regional organizations, particularly on public ownerships, have incorporated retention approaches into policy and to varying degrees into effective practice, even when timber production is still a primary objective for management (Table 1 ). While certainly an improvement over approaches that disregard the natural model of development, these recommendations mostly reflect thinking about this ecosystem in terms of a severe, infrequent disturbance regime, rather than a mixed-severity disturbance regime.

However, there are some organizations using approaches for retention that better reflect the full suite of considerations for VRH that follow from an understanding of the natural model of development for the ecosystem. In the next section, the VRH approach of one such organization is highlighted, namely the Chippewa $\mathrm{Na}$ tional Forest in north central Minnesota, USA.

VRH in red pine ecosystems on Chippewa National Forest Under a natural disturbance regime, red pine ecosystems on the USDA Forest Service's Chippewa National Forest (CNF), located in north central Minnesota, USA, have a woodland structure, with an open and patchy canopy. As in other parts of the region, these ecosystems are actually mixed in tree species compositions, dominated by red pine, but containing a variety of other species ( $\mathrm{MN}$ DNR 2003).

Historically, management of these ecosystems on the $\mathrm{CNF}$ and elsewhere in the region uses an even-age regeneration system, mostly clearcutting, with planting of largely red pine at high densities. More recently, the CNF started using VRH, along with diversified regeneration practices, in natural fire origin stands and older plantations to transition them back towards more natural composition and structure, in order to meet a broader suite of ecosystem objectives. Prescriptions can include substantial live tree retention of red pine, as well as eastern white pine and or other species when present. Stand-wide basal areas of retained trees may be on the order of 9 to $16 \mathrm{~m}^{2} / \mathrm{ha}$. Live tree retention patterns may range from dispersed to aggregated, often in the same unit (Fig. 8). Retention of large snags and logs on the ground is standard practice. Given the long-term exclusion of frequent surface fires from these ecosystems, additional activities, including mechanical scarification and woody shrub reduction, are required to facilitate tree establishment from planting and from natural regeneration. The focus of regeneration is to enhance the diversity of native trees species in the stand, i. e., not just red pine regeneration.

\section{Ecosystem responses to VRH based on a natural model} Notably, the CNF has implemented a VRH demonstration that uses a large gap/intact matrix approach (Palik et al. 2014) that emulates the spatial pattern of cohort structure resulting from natural disturbance, as discussed previously (e.g., Fig. 4). Harvested in winter 
Table 1 Examples of organizations and agencies that recommend some form of retention in their red pine management guides

\begin{tabular}{|c|c|c|}
\hline Entity & Ecological objectives & $\begin{array}{l}\text { Retention } \\
\text { consideration }\end{array}$ \\
\hline $\begin{array}{l}\text { Wisconsin } \\
\text { Department of } \\
\text { Natural Resource } \\
\text { https://dnr.wi.gov/ } \\
\text { topic/ } \\
\text { ForestManagement/ } \\
\text { guidelines.html }\end{array}$ & $\begin{array}{l}\text { Provision of wildlife } \\
\text { habitat; production of } \\
\text { diverse ecological } \\
\text { benefits }\end{array}$ & $\begin{array}{l}\text { Retain some mature } \\
\text { red pines at harvest if } \\
\text { shoot blight is not a } \\
\text { concern; retain snags } \\
\text { that are not a safety } \\
\text { concern }\end{array}$ \\
\hline $\begin{array}{l}\text { Minnesota Forest } \\
\text { Resources Council } \\
\text { http://www.mn.gov/ } \\
\text { frc/forest- } \\
\text { management- } \\
\text { guidelines.html }\end{array}$ & $\begin{array}{l}\text { Retaining habitat } \\
\text { structure after harvest }\end{array}$ & $\begin{array}{l}\text { Leave some live trees } \\
\text { during harvest as } \\
\text { either } 5 \% \text { of harvest } \\
\text { unit in clumps ( }>0.1 \\
\text { ha) or } 15-30 \\
\text { scattered trees per } \\
\text { hectare or a } \\
\text { combination of these; } \\
\text { retain all snags and } \\
\text { large logs }\end{array}$ \\
\hline $\begin{array}{l}\text { Ontario Ministry of } \\
\text { Natural Resources } \\
\text { and Forestry } \\
\text { https://www.ontario. } \\
\text { ca/document/tree- } \\
\text { marking }\end{array}$ & $\begin{array}{l}\text { Maintenance of stand } \\
\text { and landscape } \\
\text { biodiversity }\end{array}$ & $\begin{array}{l}\text { Protection of (trees } \\
\text { containing) stick } \\
\text { nests, cavity trees, } \\
\text { mast trees, super } \\
\text { canopy trees }\end{array}$ \\
\hline
\end{tabular}

2002-2003, this VRH demonstration is designed to jumpstart the restoration of woodlands with two-cohort age structure and mixed-species composition in what at the time were even-aged, dense red pine-dominated stands (Fig. 9).

Variables that are monitored as part of this demonstration include natural and planted tree regeneration (Montgomery et al. 2013; Roberts et al. 2017), plant resource availability (Boyden et al. 2012), tree productivity (Palik et al. 2014), song bird communities (Shea et al. 2017), ground layer plant communities (Roberts et al. 2016), disease responses (Ostry et al. 2012), and various tree physiological responses to retention (Powers et al. 2009, 2011). In this work, the responses of monitored variables are compared between the large gap/intact matrix configuration of VRH and dispersed retention, with the latter being a configuration that probably is less emulative of the natural model, but is more likely to be implemented in timber-focused programs that have added VRH.

Some key messages have emerged from this comparison that help to inform the development of VRH approaches. (1) Total stand-wide productivity of tree regeneration is largely invariant to spatial pattern of retention; however, growth of less shade-tolerant species such as red pine and jack pine can be higher with the large gap/intact matrix pattern compared to dispersed retention. If the a goal of management is to favor the establishment and growth of these shade intolerant species, then the pattern based on a natural model of development may be the superior choice. (2) Resource competition from woody shrubs can have an equal or greater influence on productivity of regeneration than that of overstory trees. Recall that historically, the abundance of woody shrubs was reduced by surface fires, but now high densities are a key challenge to pine regeneration. Growth is actually greater in the large gap/intact matrix configuration when combined with woody shrub reduction than it is an open, no retention setting without woody shrub reduction. If managers address both components of resource competition on regeneration, including overstory trees and woody shrubs, then use of a natural model for VRH does not result in an overly inhibitive reduction in productivity. (3) Songbird abundance is largely invariant to pattern of retention; however, species richness is higher with the large gap/intact matrix configuration compared to dispersed retention. (4) Response of ground layer plant communities, including cover/abundance of different functional groups, is largely invariant to retention pattern. The similar responses of bird and plant communities to spatial pattern of retention suggest no loss of biodiversity benefit with the natural model compared to dispersed retention. (5) Finally, several anecdotal or unpublished observations are worth noting. First, the overwhelming preference of observers on tours of this installation prefer the configuration of large gaps and intact matrix over dispersed retention. It is visually appealing and self-evident that it represents a closer

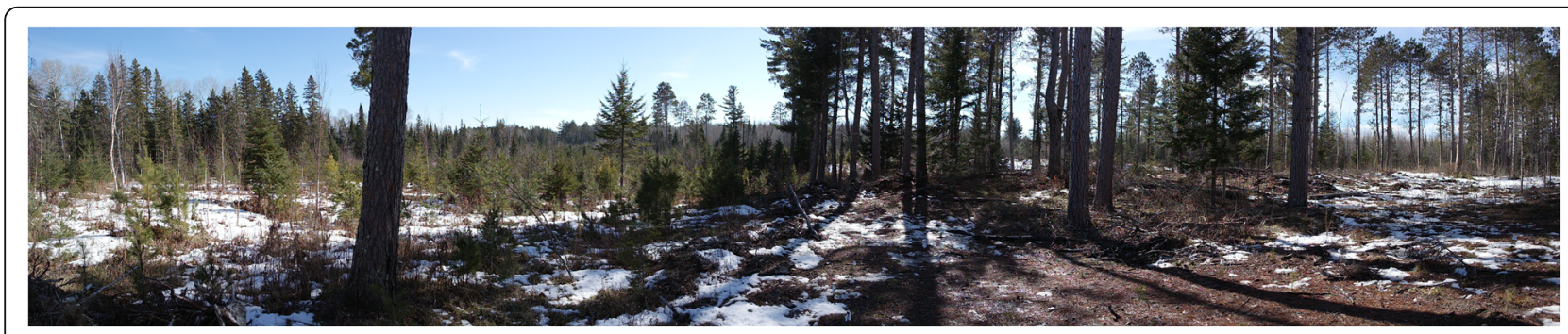

Fig. 8 VRH in a red pine-dominated ecosystem on the Chippewa National Forest, USA, including dispersed trees (left foreground) and small aggregate (center background). (Circa 2016) 


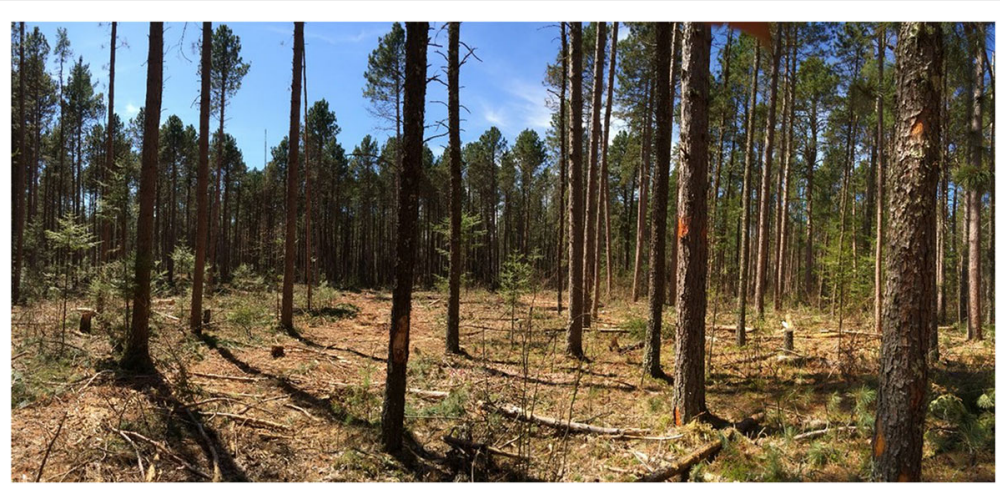

Fig. 9 Large gap/intact matrix configuration of VRH in a red pine stand on the Chippewa National Forest, USA. The photo looks into an approximately 0.2 ha opening. (Circa 2016)

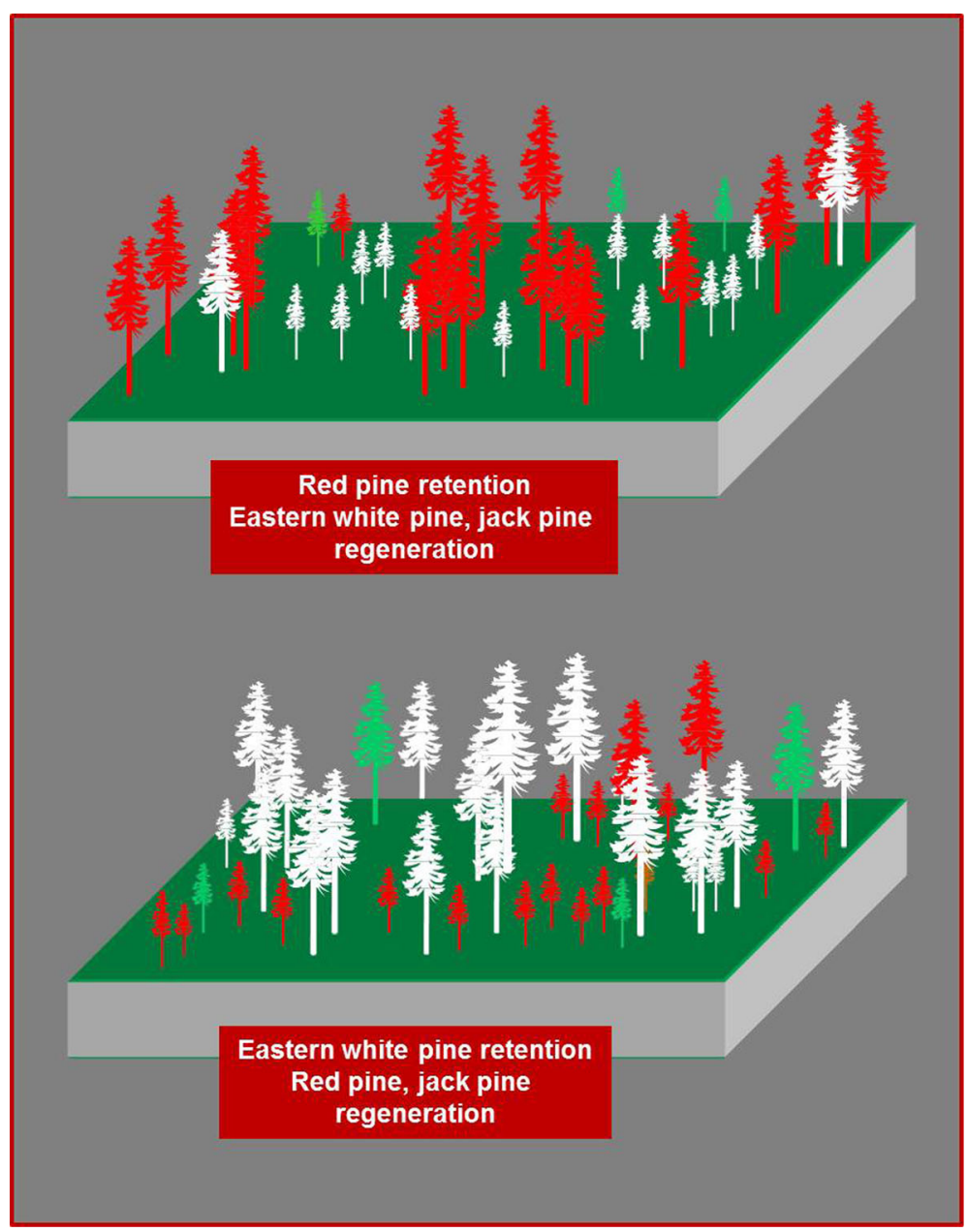

Fig. 10 Conceptual representation of alternation of pine dominance when shoot blight disease of red pine is a concern. In the figures, red pine are colored red, eastern white pine are colored white, and jack pine are colored green. Dominant composition of retention trees shifts between red pine (top) and eastern white pine (bottom) with regeneration focused on the opposite species and any additional native species. This alternation breaks up the spatial association of overstory red pine with resident shoot blight with highly susceptible red pine regeneration 
approximation of the natural model than does dispersed retention. Second, the loggers that implemented the VRH prefer the large gap/intact matrix model over dispersed retention. It is more efficient as measured by time per unit harvest volume than dispersed retention, with less potential for residual tree damage. Finally, unpublished data on tree blowdown over several years since VRH implementation confirm that residual trees are less prone to blowdown when aggregated into the large gap/intact matrix configuration than when dispersed. Trees in the former configuration may provide more mutual protection from strong winds and thus are less likely to suffer damage.

\section{Emulating a natural model with VRH under less than natural conditions}

A unique aspect of using VRH in red pine ecosystems on the CNF and in other parts of the western Great Lakes region relates to the increased occurrence of several fungal pathogens (including Sirococcus conigenus and Diplodia pinea) that cause shoot blight and mortality of regenerating pines, especially red pine (Ostry et al. 2012). Susceptibility of seedlings to the pathogens is most severe when growing near infected overstory trees, since the latter serve as the source of inoculating spores. It is not clear why the occurrence of these pathogens has increased over time, but it may be related to a general lack of surface fire use in the contemporary landscape.

The widely accepted management approach for addressing the potential for shoot blight infection is to simplify age structures of red pine stands by managing for even-age structure with no retention of any level. This can greatly reduce the potential for shoot blight diseases, but unfortunately doing so runs contrary to the natural age structure of these ecosystems, which as we have illustrated can include two- and three-cohort and broadly single-cohort stands, all of which put regenerating red pine in close proximity to overstory trees.

An approach used on the CNF for managing red pine forests with retention when there is known or suspected shoot blight issues is to use an alteration of pine dominance concept that depends on diversifying the composition of trees in ways that break up the cycle of shoot blight infection, but is still consistent with the natural model for the ecosystem. For example, an initial VRH may employ retention of live red pine as legacies, with regeneration focused largely on other species native to the ecosystem, notably eastern white pine, jack pine, and oaks. Alternatively, VRH might retain mature eastern white pine and other species, which then presents opportunities to focus regeneration on red pine and other species. In both examples, future VRH's would then alternate the composition of pine retention and regeneration so as to break up the association of mature and regenerating red pine in space (Fig. 10). This approach still maintains a complex age structure and mixed-species composition in the stand, both of which are characteristics of the natural model for the ecosystem. Common sense is also employed in that red pine may be the focus of regeneration, even with retention of mature red pine, when shoot blight has not been an issue in the area of interest.

\section{Conclusions}

While more organizations are incorporating some form of VRH into policy and practice for red pine ecosystems, this often is not based on a comprehensive understanding of the natural model of disturbance/development for these ecosystems as we have presented it here. The same disconnect between good intentions and ecological understanding may well be true for other forest types characterized by a mixed-severity disturbance/development model, or indeed other types with disturbance regimes that are more complicated than the severe, infrequent disturbance type. As we have done for red pine ecosystems, this disconnect can be addressed by considering how a deeper understanding of natural disturbance and stand development translates into VRH approaches that better emulate the natural model. While our focus is on red pine-dominated ecosystems of the western Great Lakes region of North America, our findings should be generally applicable to other forest types characterized by similar disturbance regimes and developmental patterns.

\section{Abbreviations \\ CNF: Chippewa National Forest; US: United States; VRH: Variable retention harvest}

\section{Acknowledgements}

The USDA Forest Service, Northern Research Station and the University of Vermont, Rubenstein School of Environment and Natural Resources, provided financial and logistic support. Thanks to Chris Webster, Michigan Technological University, who first suggested the idea to BP of alternation of pine dominance to mitigate shoot blight disease on red pine.

Availability of data and materials

Data sharing is not applicable to this article as no datasets were generated or analyzed during the current study.

\section{Authors' contributions}

$\mathrm{BP}$ conceived of this work in collaboration with AD. BP outlined and wrote $70 \%$ of the manuscript. AD wrote $30 \%$ of the manuscript and provided input and editing to the entire document. The authors read and approved the final manuscript.

Ethics approval and consent to participate Not applicable.

Consent for publication

Not applicable.

Competing interests

The authors declare that they have no competing interests. 


\section{Publisher's Note}

Springer Nature remains neutral with regard to jurisdictional claims in published maps and institutional affiliations.

\section{Author details}

'USDA Forest Service, Northern Research Station, Grand Rapids, MN 55744, USA. ${ }^{2}$ Rubenstein School of Environment and Natural Resources, University of Vermont, Burlington, VT 05095, USA.

Received: 29 January 2019 Accepted: 26 April 2019

Published online: 27 May 2019

\section{References}

Aubry KB, Halpern CB, Maguire DA (2004) Ecological effects of variable retention harvests in the northwestern United States: the DEMO study. For Snow Landsc Res 78:119-137

Bergeron Y, Brisson J (1990) Fire regime in red pine stands at the northern limit of the species' range. Ecology 71:1352-1364

Bergeron Y, Harvey B, Leduc A, Gauthier S (1999) Forest management guidelines based on natural disturbance dynamics: stand- and forest-level considerations. For Chron 75:49-54

Bergman HF (1924) The composition of climax plant formations in Minnesota. Pap Mich Acad Sci Arts Lett 3:51-60

Boyden S, Montgomery R, Reich PB, Palik B (2012) Seeing the forest for the heterogeneous trees: stand-scale resource distributions emerge from treescale structure. Ecol Appl 22:1578-1588

D'Amato AW, Palik BJ, Franklin JF, Foster DR (2016) Exploring the origins of ecological forestry in North America. J For 115:126

Drobyshev I, Goebel PC, Hix DM, Corace RG, Semko-Duncan ME (2008a) Pre-and post-European settlement fire history of red pine dominated forest ecosystems of Seney National Wildlife Refuge, Upper Michigan. Can J For Res 38:2497-2514

Drobyshev I, Goebel PC, Hix DM, Corace RG, Semko-Duncan ME (2008b) Interactions among forest composition, structure, fuel loadings and fire history: a case study of red pine-dominated forests of Seney National Wildlife Refuge, Upper Michigan. For Ecol Manag 256:1723-1733

Eyre FH, Zehngraff P (1948) Red pine management in Minnesota. USDA circular 778, p 70

Franklin JF, Johnson KN, Johnson DL (2018) Ecological forest management. Waveland Press, Long Grove

Franklin JF, Lindenmayer DB, MacMahon JA, McKee A, Magnusson J, Perry DA, Waide R, Foster D (2000) Threads of continuity: ecosystem disturbances, biological legacies and ecosystem recovery. Conserv Biol Pract 1:8-16

Franklin JF, Mitchell RJ, Palik B (2007) Natural disturbance and stand development principles for ecological forestry. USDA forest service General Technical Report NRS-19

Fraver S, Palik B (2012) Stand and cohort structures of old-growth Pinus resinosadominated forests of northern Minnesota, USA. J Veg Sci 23:249-259

Frelich LE (1995) Old forest in the Lake states today and before European settlement. Nat Areas J 15:157-167

Gustafsson L, Baker SC, Bauhus J, Beese WJ, Brodie A, Kouki J, Lindenmayer DB, Lõhmus A, Pastur GM, Messier C, Neyland M, Palik B, Sverdrup-Thygeson A, Volney WJA, Wayne A, Franklin JF (2012) Retention forestry to maintain multifunctional forests: a world perspective. Bioscience 62:633-645

Guyette R, Gallagher T, Palik B, Dey D, Stambaugh M (2015) Early fire history at the Cutfoot experimental Forest. Preliminary report. The Missouri Tree-Ring Laboratory, University of Missouri, Columbia

Hansen A, Spies T, Swanson F, Ohmann J (1991) Conserving biodiversity in managed forests. BioScience 41:382-392

Heinselman M (1996) The boundary waters wilderness ecosystem. University of Minnesota Press, Minneapolis

Kuuluvainen T, Siitonen J (2013) Fennoscandian boreal forests as complex adaptive systems. Properties, management challenges and opportunities. In: Messier C, Puettman KJ, Coates KD (eds) Managing forests as complex adaptive systems: building resilience to the challenge of global change. Routledge Press, Abingdon Loope WL, Anderton JB (1998) Human vs. lightning ignition of presettlement surface fires in coastal pine forests of the upper Great Lakes. Am Midl Nat 140:206-218

McLaughlin JA (2001) Impact of Armillaria root disease on succession in red pine plantations in southern Ontario. For Chron 77:519-524
Minnesota Forest Resources Council (2013) Sustaining Minnesota forest resources: voluntary site-level forest management guidelines for landowners, loggers and resource managers. Minnesota Forest Resources Council, St. Paul

MN DNR (2003) Field guide to the native plant communities of Minnesota: The Laurentian mixed forest province. Ecological Land Classification Program, Minnesota County Biological Survey, and Natural Heritage and Nongame Research Program, Minnesota Department of Natural Resources, St. Paul

Montgomery RA, Palik BJ, Boyden SB, Reich PB (2013) New cohort growth and survival in variable retention harvests of a pine ecosystem in Minnesota, USA For Ecol Manage 310:327-335

Ostry ME, Moore MJ, Kern CC, Venette RC, Palik BJ (2012) Multiple diseases impact survival of pine species planted in red pine stands harvested in spatially variable retention patterns. For Ecol Manag 286:66-72

Palik BJ, D'Amato AW (2017) Ecological forestry: much more than retention harvesting. J For 115:51

Palik BJ, Montgomery RA, Reich PB, Boyden SB (2014) Biomass growth response to spatial pattern of variable-retention harvesting in a northern Minnesota pine ecosystem. Ecol Appl 24:2078-2088

Powers MD, Pregitzer KS, Palik BJ, Webster C (2011) The physiological basis for regeneration response to variable retention harvest treatments in three pine species. Forestry 84:3-22

Powers MD, Webster CR, Pregitzer KS, Palik BJ (2009) Spatial dynamics of radial growth and efficiency in residual Pinus resinosa following aggregated retention harvesting. Can J For Res 39:109-117

Roberts MW, D'Amato AW, Kern CC, Palik BJ (2016) Long-term impacts of variable retention harvesting on ground-layer plant communities in Pinus resinosa forests. J Appl Ecol 53:1106-1116

Roberts MW, D'Amato AW, Kern CC, Palik BJ (2017) Effects of variable retention harvesting on natural tree regeneration in Pinus resinosa (red pine) forests. For Ecol Manag 385:104-115

Shea EL, Schulte LA, Palik BJ (2017) Decade-long bird community response to the spatial pattern of variable retention harvesting in red pine (Pinus resinosa) forests. For Ecol Manag 402:272-284

Shirley HL (1932) Light intensity in relation to plant growth in a virgin Norway pine forest. J Agric Res 44:227-244

Silver EJ, Fraver S, D'Amato AW, Aakala T, Palik BJ (2013) Long-term mortality rates and spatial patterns in an old-growth Pinus resinosa forest. Can J For Res 43:809-816

Watkins $L$ (2011) The forest resources of Ontario 2011. Ontario Ministry of Natural Resources, Forest Evaluation and Standards Section, Forests Branch, Sault Ste. Marie, p 307

\section{Submit your manuscript to a SpringerOpen ${ }^{\circ}$ journal and benefit from:}

- Convenient online submission

- Rigorous peer review

- Open access: articles freely available online

- High visibility within the field

Retaining the copyright to your article

Submit your next manuscript at $\boldsymbol{\nabla}$ springeropen.com 